УДК 94(517)

БАЗАРОВ Виктор Борисович - кандидат исторических наук, научный сотрудник Института монголоведения, буддологии и тибетологии СО РАН (670047, Россия, Республика Бурятия, г. Улан-Удэ, ул.Сахьяновой, 6; bazarov_science@таil.ru)

\title{
МОНГОЛО-АМЕРИКАНСКИЕ ОТНОШЕНИЯ В КОНЦЕ XX - НАЧАЛЕ XXI в.
}

\begin{abstract}
Аннотация. После смены политического строя, в конце XX столетия Монголия приняла новую концепцию внешней политики, которая отвечала вызовам многополярного мира. Наряду с основными внешнеполитическими партнерами Монголии - Россией и Китаем - важная роль отводилась «третьему соседу» как дополнительному балансировочному противовесу. Согласно Концепции внешней политики Монголии, роль «третьего соседа» должны играть индустриально развитые страны: США, страны Европейского союза, Япония и др. Надо понимать, что США, взаимодействуя с Монголией, работают на постсоветском пространстве, создают дополнительную активность в регионе в непосредственной близости с Россией и Китаем. На основе открытых официальных источников дается оценка динамики внешнеполитического диалога между Монголией и США, внешнеэкономических связей, взаимодействия в различных направлениях, в т.ч. и в области военного сотрудничества.
\end{abstract}

Ключевые слова: Монголия, США, внешняя политика, военное сотрудничество, внешнеторговый оборот

$\mathrm{M}$ онголо-американские дипломатические отношения были установлены в 1987 г., а в 1988 г. в столице Монголии было открыто посольство США 1 . Однако первый американский посол Джозеф Лейк прибыл в г. Улан-Батор только в 1990 г. Монголия же аккредитовала своего посла в США в марте 1989 г.

Визиты на высшем уровне состоялись в начале 1990-х гг. Госсекретарь Джеймс Бейкер посетил Монголию в августе 1990 г., затем в июле 1991 г. В январе 1991 г. президент Монголии П. Очирбат посетил США по приглашению президента США Дж. Буша-старшего, а в июне 1991 г. - премьер-министр Монголии Д. Бямбасурэн. Во время двусторонних переговоров было подписано соглашение о предоставлении Монголии американской помощи в размере 2 млн долл. США на развитие образования, заключены межправительственные соглашения о сотрудничестве сторон в области торговли, науки и техники, была создана рабочая группа по торгово-экономическому сотрудничеству. При поддержке и содействии США Монголию приняли в Международный валютный фонд и Всемирный банк (14 февраля 1991 г.), а монгольские руководители заручились поддержкой Генерального секретаря ООН Переса де Куэльяра в предоставлении Монголии помощи по линии ПРООН и ЮНИСЕФ.

В марте 1991 г. конгресс США одобрил политику американского правительства по развитию сотрудничества с Монголией в политической, экономической, научной и культурной областях. В преддверии визита президента Монголии Н. Энхбаяра в США в 2001 г. конгресс США предоставил льготные условия торговли для Монголии. В результате этот визит окрестили как установление стратегического партнерства с США [История Монголии... 2007: 393]. Руководящий совет корпорации «Вызовы тысячелетия» включил Монголию в свою программу поддержки.

С начала нулевых годов идет интенсивный политический диалог на высшем уровне. Монголию посещали с официальными визитами заместитель госсекре-

1 U.S. relations with Mongolia [Отношения США и Монголии]. - Государственный департамент США. Официальный сайт. URL: http://www.state.gov/r/pa/ei/bgn/2779.htm (accessed 05.06.2018). 
таря Ричард Армитаж (январь 2004 г.), спикер палаты представителей Деннис Хастерт (август 2005 г.), министр обороны Дональд Рамсфелд (октябрь 2005 г.)1․ Примечателен обмен визитами президентов Монголии и США в 2004 и 2005 гг. Причем Дж. Буш-младший в ноябре 2005 г. стал первым президентом США, посетившим новую Монголию. В ходе встреч было подписано соглашение о создании совместного совета по торговле и инвестициям. Стороны договорились о создании предпосылок для заключения двустороннего соглашения о свободной торговле, а фонд «Вызовы тысячелетия» был определен как основная программа помощи развитию Монголии. Также было решено, что Монголия получит 11 млн долл. США в рамках инициативы «Солидарность» - за содействие усилиям по борьбе с терроризмом и демократическому строительству.

22 октября 2007 г. во время официального визита президента Монголии Н. Энхбаяра в США был подписан проект фонда «Вызовы тысячелетия» для Монголии. В рамках этого проекта-договора выделялась безвозмездная помощь Монголии в размере 285 млн долл. для осуществления проектов по нескольким направлениям инфраструктурного, образовательного, институционального характера, основной целью которых было снижение уровня бедности в Монголии ${ }^{2}$ Монголия также вошла в ряд других программ поддержки со стороны США, таких как программа Американского агентства международного развития $(U S A I D)$, которая ставила целью добиться устойчивого роста частного сектора и более эффективного управления. Общая помощь USAID Монголии в 1991-2008 гг. составила приблизительно 174,5 млн долл. Также министерство сельского хозяйства США включило Монголию в 416 продовольственных программ. Доходы от реализации продовольственной помощи использовались для поддержки предпринимательства, улучшения жизненных условий скотоводов, повышения качества ветеринарных услуг.

Однако в силу объективных причин торговля и экономическое сотрудничество Монголии и США развивались медленными темпами и в ограниченных масштабах (см. табл. 1).

Таблица 1

Внешнеторговый оборот между Монголией и США, 1992-2007 гг., млн долл. США*

\begin{tabular}{|l|c|c|c|c|c|c|c|c|c|c|c|c|}
\hline \multicolumn{1}{|c|}{ Годы } & $\mathbf{1 9 9 2}$ & $\mathbf{1 9 9 4}$ & $\mathbf{1 9 9 6}$ & $\mathbf{1 9 9 9}$ & $\mathbf{2 0 0 0}$ & $\mathbf{2 0 0 1}$ & $\mathbf{2 0 0 2}$ & $\mathbf{2 0 0 3}$ & $\mathbf{2 0 0 4}$ & $\mathbf{2 0 0 5}$ & $\mathbf{2 0 0 6}$ & $\mathbf{2 0 0 7}$ \\
\hline $\begin{array}{l}\text { Товарооборот } \\
\text { всего, в т.ч.: }\end{array}$ & 6,2 & 23,8 & 28,9 & 77,8 & 110,1 & 159,4 & 189,1 & 166,4 & 202,8 & 189,6 & 162,6 & 155,6 \\
\hline Экспорт & 4,4 & 12,4 & 17,8 & 46,3 & 85,8 & 144,5 & 165,7 & 142,9 & 156,3 & 152,5 & 119,0 & 99,9 \\
\hline Импорт & 1,8 & 11,4 & 11,1 & 31,5 & 24,3 & 14,9 & 23,4 & 23,5 & 46,5 & 37,1 & 43,6 & 55,7 \\
\hline
\end{tabular}

* Составлено по данным официальной монгольской статистики за соответствующие годы. См.: Монгол Улсын статистикийн эмхтгэл... 2009. С. 271; 2012. С. 265; 2014. С. 275; 2016. С. 459.

Заметный рост монгольского экспорта в 2001-2002 гг. можно объяснить введением льготных торговых условий для Монголии в США в 2001 г., причем импорт американской продукции остается на стабильно низком уровне.

1 Китайский бросок Рамсфелда. - Аналитическое издание «Новые известия». Официальный сайт. 19.10.2005. Доступ: http://www.newizv.ru/news/2005-10-19/33736/ (проверено 05.06.2018).

2 Монголы нашли «третьего соседа». - Новостное издание Zabinfo.ru. Официальный сайт. 24.10.2007. Доступ: http://zabinfo.ru/39544 (проверено 04.06.2018). 
Военное сотрудничество Монголии и США началось также в начале нулевых годов. Монголия принимала участие в контртеррористических совместных операциях в Ираке и в Афганистане в 2003 г., миротворческих миссиях по линии ООН и НАТО в 2005 г. При этом США поддерживали реформу оборонной отрасли Монголии, направленную на рост численности ее вооруженных сил.

С 2003 г. под патронажем министерства обороны США проводились регулярные совместные учения Khan Quest. В 2006 г. США удалось добиться включения Khan Quest в реестр международных учений, проводимых под эгидой ООН. Учения Khan Quest 2006 собрали 850 военнослужащих из Монголии, США и 242 солдат из Фиджи, Тонги, Таиланда, Бангладеша и Индии под наблюдением Великобритании, Франции, Италии, Японии, России и Южной Кореи 1 . В учениях Khan Quest 2007 приняли участие 600 монгольских военнослужащих, а также военнослужащие из Южной Кореи, Бангладеша, Тонги, Шри-Ланки, Индонезии, Камбоджи и США. Наблюдателей за учениями прислали из России, КНР и Японии. Учения проходили вблизи монголо-китайской границы в местности Тавантолгой. Бюджет мероприятия составил 3,4 млн долл. США, финансировалось оно Международной программой США по поддержке мирных инициатив (U.S. World Peace Initiative Support Program).

Международные учения Khan Quest 2008 проводились в сентябре 2008 г. Перенос сроков учения с весны на осень произошел в связи с тем, что Китай заявил о нежелательности проведения таких учений в период Пекинской Олимпиады $2008^{2}$ и предупредил, что в период проведения игр Пекин не предоставит воздушный коридор американской военной авиации, дислоцирующейся в Японии и Южной Кореe. В Khan Quest 2008 приняли участие 360 военнослужащих из Монголии, Индии, Таиланда, Непала и США. Миротворческие учения Khan Quest стали одним из самых широкомасштабных учений в АТР, направленных на «поддержку и развитие миротворческой способности стран АзиатскоТихоокеанского региона» ${ }^{3}$.

25 февраля 2016 г. заместитель начальника Генерального штаба Вооруженных сил Монголии бригадный генерал Р. Сухбат принял заместителя командующего Национальной гвардии ВВС США в Тихом океане генерал-майора Майка Комптона. Стороны договорились о совместной деятельности в рамках Программы развития монголо-американского сотрудничества в оборонной отрасли ${ }^{4}$.

Динамичное военное сотрудничество Монголии и США идет на фоне активного внешнеполитического диалога между странами. Так, в июне 2015 г. в рамках форума «Камка-2015», организованного совместными усилиями Минобороны Монголии, фонда Рамсфельда, Ассоциации развития бизнеса в Монголии (Монголын бизнес хугжлийн холбоо) и фонда «Зориг», в Монголию прибыл экс-министр обороны США Дональд Рамсфельд, где он впервые побы-

\footnotetext{
1Mongolia holds khan quest military exercise [Монголия проводит военные учения «в поисках хана»]. The Jamestown foundation. 11.07.2008. Доступ: https://jamestown.org/program/mongolia-holds-khan-questmilitary-exercise/ (проверено 04.06.2018)

2 «Революция юрт»: Военные интересы США в Монголии столкнулись с Олимпиадой, учения Khaan Quest отложены. - Информационное агентство Regnum. Официальный сайт. 02.07.2008. Доступ: https://regnum.ru/news/1022260.html (проверено 04.06.2018).

3 Khaan Quest 2016 Officially Ends with Closing Ceremony [Хан Квест 2016 официально завершились]. - Посольство США в Монголии. Официальный сайт. 04.06.2016. URL: https://mn.usembassy.gov/khaanquest-2016-officially-ends-closing-ceremony/ (accessed 05.06.2018).

4 Обсуждены вопросы укрепления воздушных войск Монголии. - Информационное агентство Polpred. Официальный сайт. 26.02.2016. Доступ: https://polpred.com/?ns=1\&ns_id=1676494 (проверено 04.06.2018).
} 
вал в 2005 г., будучи еще министром обороны США ${ }^{1}$ В форуме приняли участие 100 делегатов из Монголии, Армении, Афганистана, Грузии, Туркменистана, Узбекистана, Казахстана и США. Кроме экономических и политических вопросов, в рамках форума обсуждались демократический опыт Монголии, внешнеторговые, инвестиционные вопросы, а также вопросы региональной безопасности и внешней политики.

23 июня 2015 г. состоялась церемония открытия проекта $R E A C H$, направленного на развитие малого и среднего бизнеса (МСБ), организованного совместными усилиями Американского агентства международного развития (USAID) и НПО «Хугжлийншийдэл» ${ }^{2}$. Участие в церемонии открытия приняли сотрудники посольств США, Японии, Южной Кореи и ЕС, постоянные представители международных организаций, а также специалисты Министерства промышленности и Фонда кредитной гарантии (ФКГ). Данный проект подразумевает сопровождение МСБ в получении кредитов, помощь в подготовке проектной документации и прочие консультационные услуги. Фонд также содействует реализации проектов МСБ совместно с Азиатским банком развития.

23-27 июня 2015 г. проходил рабочий визит премьер-министра Монголии Ч. Сайханбилэга в США. В первый же день визита премьер-министр провел встречу с профессором медицинской школы Стэндфордского университета Джеффри Гленом. Стороны обсудили предложения по строительству в Монголии биотехнологического и биофармацевтического предприятия на сумму 20-30 млн долл. США, а также вопросы ведения соответствующих совместных научно-исследовательских работ.

Также премьер-министр Ч. Сайханбилэг принял делегацию Всемирного банка во главе с исполнительным директором Ш. Индравати ${ }^{3}$. В рамках встречи стороны обсудили вопросы денежной политики в условиях экономических и бюджетных осложнений, договорились о финансовой компенсации бюджетных убытков Монголии на 100 млн долл. США. В ходе визита было проведено значительное число встреч с высокопоставленными чиновниками США, конгрессменами, вице-президентом США Джо Байденом, с делегациями крупных инвестиционных групп и фондов. Последние выразили готовность инвестировать средства в горнорудную промышленность Монголии и в производство кашемира.

В июле 2015 г. состоялся официальный визит министра иностранных дел Монголии Л. Пурэвсурэна в США, который провел встречу с госсекретарем США Дж. Керри. Стороны обсудили возможности активного участия и сотрудничества по вопросам безопасности и экономической интеграции в АзиатскоТихоокеанском регионе, в Северо-Восточной Азии ${ }^{4}$ Вскоре в г. Улан-Баторе прошла 10-я консультативная встреча между МИДом Монголии и госдепартаментом США. Делегацию с монгольской стороны возглавлял госсекретарь

1 «КАМКА-2015» пройдет 10-21 июня в Улаанбаатаре. - Информационное агентство Polpred. Официальный сайт. 18.06.2015. Доступ: https://polpred.com/?ns=1\&ns_id=1402979 (проверено 05.06.2018).

2 Правительство США поддержит малый и средний бизнес Монголии. - Информационное агентство Polpred. Официальный сайт. 23.06.2016. Доступ: https://polpred.com/?ns=1\&ns_id=1810070 (проверено 04.06.2018).

3 Второй день рабочего визита в США премьер-министра Ч. Сайханбилэга. - Информационное агентство Polpred. Официальный сайт. 25.06.2015. Доступ: https://polpred.com/?ns=1\&ns_id=1420533 (проверено 04.06. 2018).

4 Министр иностранных дел Л. Пурэвсурэн встретился с Государственным секретарем США Д. Керри. - Информационное агентство «Монголия Сейчас». Официальный сайт. 16.07.2015. Доступ: http://news.mongolnow.com/16_07_02.html (проверено 04.06.2018). 
МИДа Д. Ганхуяг, с американской - секретарь-помощник госдепартамента США по восточноазиатским и тихоокеанским вопросам Дэниель Рассел.

В июле 2015 г. на празднование 25-летия первых демократических выборов в Монголии прибыл президент Международного республиканского института США (International Republican Institute) Марк Грин. Он провел встречу со спикером ВГХ 3. Энхболдом, во время которой он передал спикеру благодарственное письмо от председателя группы монголо-американской дружбы при палате представителей США Петера Роскама с высокой оценкой деятельности сотрудничества ВГХ Монголии и палаты представителей США.

Госсекретарь США Джон Керри 5 июня 2016 г. прилетел в Монголию с официальным визитом по приглашению министра иностранных дел Монголии Л. Пурэвсурэна ${ }^{1}$. Дж. Керри подчеркнул, что Монголия, находящаяся между двумя сложными соседями, является оазисом демократии. Монголия, расположенная между Китаем и все более активно выступающей против Вашингтона Россией, является дружественным союзником США. При этом Керри добавил, что иностранное инвестирование в Монголию прекратилось из-за недоработок бизнес-законов.

Помимо снижения инвестирования, с 2013 г. наблюдалось серьезное падение торгового оборота между США и Монголией (см. табл. 2). Более того, во внешнеторговом обороте доля экспорта монгольских товаров в США резко сократилась с 2009 г., что привело к сильному дисбалансу, отрицательному сальдо внешнеторгового оборота. Объемы монголо-американской торговли не могут конкурировать в абсолютном измерении с объемом монголо-китайской торговли.

Таблица 2

Внешнеторговый оборот между Монголией и США, 2008-2016 гг., млн долл. США*

\begin{tabular}{|c|c|c|c|c|c|c|c|c|c|}
\hline Годы & $\mathbf{2 0 0 8}$ & $\mathbf{2 0 0 9}$ & $\mathbf{2 0 1 0}$ & $\mathbf{2 0 1 1}$ & $\mathbf{2 0 1 2}$ & $\mathbf{2 0 1 3}$ & $\mathbf{2 0 1 4}$ & $\mathbf{2 0 1 5}$ & $\mathbf{2 0 1 6}$ \\
\hline Товарооборот всего, в т.ч.: & 198,3 & 117,6 & 164,9 & 541,1 & 539,5 & 516,6 & 244,8 & 135,2 & 149,7 \\
\hline Экспорт & 114,2 & 13,9 & 6,0 & 5,0 & 3,6 & 3,9 & 15,4 & 18,7 & 10,5 \\
\hline Импорт & 84,1 & 103,7 & 158,9 & 536,0 & 535,9 & 512,7 & 229,5 & 116,5 & 139,2 \\
\hline
\end{tabular}

* Монгол Улсын статистик ийнэмхтгэл... 2009. С. 271; 2012. С. 265; 2014. С. 275; 2016. С. 459.

Таким образом, начиная с 1990-х гг. шел интенсивный внешнеполитический диалог между Монголией и США, на регулярной основе проходил обмен визитами на высшем уровне. Монголия получила от США серьезную политическую, финансовую, институциональную поддержку. Финансовая поддержка США осуществлялась через различные крупные международные фонды и программы, характер которых был безвозмездным или в виде льготного кредитования. На международном политическом уровне Монголия и США совместно поддерживали демократические инициативы, в т.ч. миротворческие операции на Ближнем Востоке. Что касается военного сотрудничества Монголии и США, то оно началось на базе операций в Ираке и Афганистане, где монгольские военнослужащие принимали активное участие. Военное сотрудничество вылилось в регулярные антитеррористические учения на территории Монголии, которые, в свою очередь, переросли в одни из самых крупных учений в АТР с применением сухопутных подразделений и авиации.

\footnotetext{
1 Госсекретарь США Керри в оазисе демократии. - Информационное агентство Аrd. Официальный сайm. 05.06.2016. Доступ: http://asiarussia.ru/news/12506/ (проверено 05.06.2018).
} 
Динамика торгового оборота между Монголией и США показывает рост, но с сильной амплитудой колебания. Объемы торговли нестабильны от года к году и сильно зависят от политических решений США. Все это происходит на фоне снижения инвестирования США, мотивированного неустойчивой и непрозрачной законодательной базой Монголии по отношению к бизнесу. При этом подчеркивается особая роль Монголии в регионе как верного союзника США.

Работа выполнена в рамках государственного задания ФАНО России (проект XII.187.1.4. ХІІ.191.1.2. «Межкультурное взаимодействие, этнические и социально-политические процессы в Центральной Азии», номер госрегистрации № AAAA-A17-117021310264-4).

\title{
Список литературы
}

История Монголии. ХХ век (под ред. Р.Б. Рыбакова). 2007. М.: Институт востоковедения РАН. 448 с.

BAZAROV Victor Borisovich, Cand.Sci. (Hist.), Researcher of the Institute of Mongolian, Buddhist and Tibetan Studies, Siberian branch of the Russian Academy of Sciences (6 Sahyanovoj St, Ulan-Ude, Republic of Buryatia, Russia; bazarov science@mail.ru)

\section{MODERN MONGOLIAN-AMERICAN RELATIONS}

\begin{abstract}
After changing the political system, at the end of the $20^{\text {th }}$ century, Mongolia adopted a new concept of foreign policy. This concept met the challenges of the multipolar world. Along with the main foreign policy partners of Mongolia, such as Russia and China, a separate role is played by the so-called third neighbor. According to the Foreign Policy Concept of Mongolia, the role of the third neighbor should play the industrially developed countries, such as the United States, European Union countries, Japan, etc. It is necessary to understand that the USA, working with Mongolia, works in the post-Soviet space, creates additional activity in the region in close proximity to Russia and China. Based on open official sources, the author gives an assessment of the dynamics of foreign policy dialogue between Mongolia and the United States, of foreign economic relations, interaction in various directions, including in the field of military cooperation.

Keywords: Mongolia, United States, foreign policy, military cooperation, foreign trade turnover
\end{abstract}

